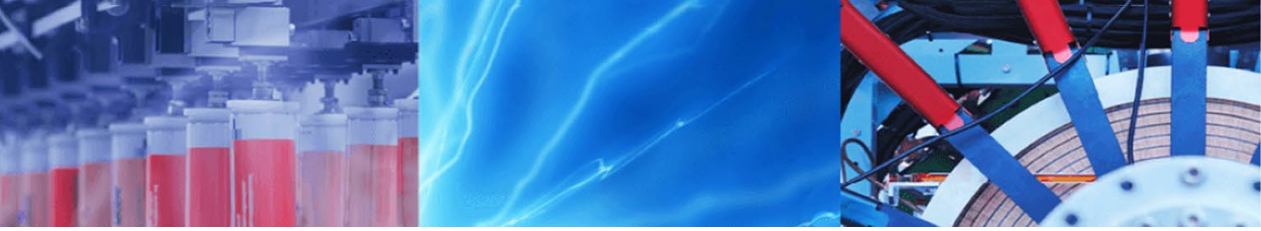

Research Article

\title{
Role of Prosopis juliflora as a botanical synergist in enhancing the efficacy of neem kernel powder against tea red spider mites, Oligonychus coffeae (Acari: Tetranychidae)
}

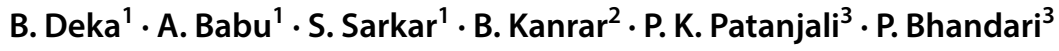

Received: 6 November 2019 / Accepted: 26 February 2020 / Published online: 9 March 2020

(c) Springer Nature Switzerland AG 2020

\begin{abstract}
A study was carried out to test the toxicity of neem kernel powder (NKP) in combination with seed powder of Prosopis juliflora, a botanical synergist, against tea red spider mites, Oligonychus coffeae. After mixing with this botanical synergist, different concentrations of the extracts of NKP were tested against eggs and adults of the red spider mite. Results of the experiments carried out under both laboratory and field conditions showed that the botanical synergist significantly enhanced the efficacy of NKP extract. Besides acting as a synergist, the botanical powder serves as an eco-friendly and environmentally safe formulation when combined with NKP for red spider mite management. It does not show any phytotoxicity to tea plants and was safer to non-target organisms. The aqueous extract prepared with the combination of NKP and botanical powder (synergist) does not leave any residues in made tea after the 7th day of application.
\end{abstract}

Keywords Neem kernel powder $\cdot$ Prosopis juliflora $\cdot$ Botanical synergist $\cdot$ Tea $\cdot$ Red spider mite

\section{Introduction}

The tea plant Camellia sinensis (L.) Kuntze belongs to the family Theaceae. It is a perennial crop known to be infested by a number of insect and mite pests, leading to an average crop loss of $12-15 \%$ per year $[4,9,19,28]$. Pest management in tea is mainly achieved by the use of synthetic chemicals [1, 18]. The use of these synthetic chemicals for the control of pests leads to several problems including pesticide residues in tea. To overcome this, adopting non-chemical control strategies has become essential. Use of biologics of plant origin has received wide acceptance for many crops including tea [27]. Although neem-based products are used in many crops, their use is limited in tea, except for certain azadirachtinbased commercial formulations. Neem (Azadirachta indica, A. Juss) is a popular tree in India; being indigenous, it is utilized for several traditional purposes in rural areas, and the products are known to have strong insecticidal properties $[14,30,31]$. Neem is a rich source of bioactive botanical constituents. The oil is a key product of neem and is obtained in varying amounts from the fruit (4.6\%), seeds (20\%) and kernels (18.5-52\%). Commercially, neem has been used in the manufacturing of soaps, candles, lubricants, toiletry, toothpastes, mosquito repellent creams, etc. At present, neembased bioproducts are also being used in plant protection. In agriculture, the non-judcious use of broad-spectrum pesticides has resulted in several undesirable effects, such as the resurgence and outbreak of pests, development of resistance to pesticides and the hazards of toxic residues to humans, non-target and beneficial organisms, etc. Currently, almost 200 insect pest are reported to be controlled by neem derivatives $[2,12]$. Synergists are natural or synthetic chemicals that are nontoxic and increase the lethality and effectiveness of insecticides by blocking the metabolic systems by breaking

\footnotetext{
$\triangle$ B. Deka, bhabesh.deka@gmail.com | ${ }^{1}$ Tea Research Association, North Bengal Regional R\&D Centre, Nagrakata, West Bengal 735225 India. ${ }^{2}$ Tea Research Association, Analytical Service, Park, Street, Kolkata, West Bengal 700016, India. ${ }^{3}$ Institute of Pesticide Formulation Technology, Gurgaon 122016, India.
} 
down insecticide molecules, which interfere with the detoxication of insecticides through their action on polysubstrate monooxygenases (PSMOs) and other enzyme systems. The botanical synergist also plays an important role in the insecticide toxicity, mode of action as well as nature of the resistance development mechanism and is not harmful to nontarget organisms [6]. About 44 species in the genus Prosopis have been identified [22]; among them, Prosopis juliffora has been widely introduced in various parts of the world including India. Throughout India, Prosopis juliflora is abundantly available in the wasteland areas [17]. Insecticidal activity of Prosopis juliflora extracts was reported against whitefly eggs and nymphs [7], the stored grain pest Tribolium castaneum [24] and mosquito vectors of malaria, dengue, chikungunya and filariasis [5, 36, 37]. Murugesan et al. [21] reported Prosopis leaf extract enhanced the pesticidal impact of endosulfan on the fecundity of Spodoptera litura.

An attempt has been made to evaluate the bioactivity of the dried seed powder of Prosopis juliflora as a botanical synergist to establish its synergistic potential in enhancing the efficacy of neem kernel powder extract against one of the major tea pests, the red spider mite, under laboratory and field conditions.

\section{Materials and methods}

\subsection{Collection and laboratory culture of red spider mites}

The adult red spider mites were collected from North Bengal Regional R\&D Centre experimental plots ( $26^{\circ} 54^{\prime} 0^{\prime \prime} \mathrm{N}$, $88^{\circ} 55^{\prime} 0^{\prime \prime}$ E longitude) in Nagrakata, West Bengal, India. The culture of red spider mites was maintained following the detached leaf culture method of Helle and Sabelis [13] under laboratory conditions $\left(25 \pm 2{ }^{\circ} \mathrm{C} ; 75 \pm 5 \% \mathrm{RH} ; 16 \mathrm{~L}: 8 \mathrm{D}\right.$ photoperiod) on a susceptible tea clone, TV1. From the stock culture, adult mites were transferred onto fresh tea leaves (approximately $6 \mathrm{~cm}^{2}$ ) placed on moistened cotton pads (ca. $1.5 \mathrm{~cm}$ thick) in plastic trays $(38 \times 28 \times 5 \mathrm{~cm})$. Withered leaves were replaced with new ones at 2-3-day intervals. These pure cultures (not exposed to any pesticides) were maintained for $>10$ generations (from the F1 to F10) under laboratory conditions $\left(25-30^{\circ} \mathrm{C}\right.$ and $75-95 \%$ humidity), and for different bioefficacy evaluations, mites were taken from the above-mentioned culture.

\subsection{Preparation of neem kernel powder (NKP) and botanical synergist extract}

The dried seeds of Prosopis juliflora used as synergist were collected from the IPFT farm, Gurgaon, India, and collected samples were shade dried at room temperature $\left(28{ }^{\circ} \mathrm{C} \pm 2{ }^{\circ} \mathrm{C}\right.$ ) and powdered using an electric blender [17]. Neem kernel powder ( $2.5 \mathrm{gm})$ was mixed with $2.5 \mathrm{~g}$ of botanical synergist and soaked in $100 \mathrm{ml}$ of water overnight. The solution was later extracted and filtered using double-layer muslin cloth to prepare the $5 \%$ concentration stock solution.

\subsection{Bioefficacy Study}

Bioassays were carried out to evaluate the bioefficacy under both laboratory (leaf disc experiment) and field conditions (micro-plot and large scale RBD trials).

\subsubsection{Leaf disc experiment}

Leaf discs ( $2 \mathrm{~cm}$ diameter) cut from tea leaves were placed on wet cotton kept in a petri dish. Moisture in the cotton was maintained throughout the study by wetting it with distilled water on a daily basis. Ten mites were released onto each leaf disc from stock culture, which was maintained in the laboratory. Different concentrations of extracts were prepared by dissolving a known quantity of the extract in distilled water kept in a beaker. Prepared spray fluid was sprayed onto the leaf disc using a glass atomizer. The distance between the atomizer and the leaf disc was kept constant ( 1 foot) to ensure that only fine droplets were falling on the leaf disc. Leaf discs sprayed with distilled water served as control. After imposing the treatment, observations were made using a simple compound microscope at a specified magnification of $10 \times$ to observe and record the mortality of mites at 24-h intervals for a 3-day period.

Percentage mortality

$=($ No. of mites dead $/$ No. of mites tested $) \times 100$

\subsubsection{Lethal concentration $\left(\mathrm{LC}_{50}\right)$ study}

For the $\mathrm{LC}_{50}$ study, a stock solution of $5 \%(2.5 \mathrm{~g} \mathrm{NKP}+2.5 \mathrm{~g}$ botanical synergist) in $100 \mathrm{ml}$ of water was prepared. From the stock solution different concentrations (viz., 0.5, 1.0, 2.0, 3.0, 4.0, 5. 0, 6.0 5.0, 8.0, 9.0 and 10\%) were prepared by dilution with distilled water. Leaf discs of $2 \mathrm{~cm}$ diameter cut from mature tea leaves were placed on wet cotton kept in a petri dish. Ten mites were released onto the leaf discs from a stock culture maintained in the laboratory. Prepared spray fluid was sprayed onto the leaf disc using a glass atomizer as mentioned earlier. Leaf discs sprayed with distilled water served as control. Moisture in the cotton was maintained throughout the study by wetting it with distilled water every day. After imposing the treatment, observations were made to record the mortality of 
mites at 24-h intervals for a 5-day period using a simple compound microscope at a specified magnification of $x$ 10. The calculated $\mathrm{LC}_{50}$ value was used as a baseline datum for further bioassays.

$\%$ reduction of mite population $=\left(\frac{(\text { Pre treatment population count }- \text { Post treatment population count })}{\text { Pre treatment population count }} \times 100\right)$ better coverage and control. Post-treatment assessments were also made in a similar manner at weekly intervals up to 30 days, and the percentage of bioefficacy was calculated.

Mean population reduction of mites per treatment was calculated using the following formula:

\subsubsection{Ovicidal activity}

For assessment of the ovicidal activity of the extract, 15 gravid female red spider mites were introduced on to a mature leaf (TV1 clone) for oviposition and kept overnight in a petri dish as described earlier. The mature leaves were padded with water-soaked cotton. After $24 \mathrm{~h}$, the introduced mites were removed with the help of a fine camel hair brush. The eggs laid on tea leaves were counted under a microscope. Tea leaves containing $>30$ eggs were removed cautiously using a fine needle. Thirty eggs were used for each treatment, and the experiments were replicated five times. The eggs were subjected to spraying using a glass atomizer with different concentrations of NKP extract with and without the botanical synergist, NKP (stand alone) @ 2.5\%, NKP @ 2.5\% mixed with botanical synergist @ 2.5\% along with a recommended standard acaricide and an untreated control (water spray). Hatchability of eggs was determined for a 12-day period after treatment. Those eggs that did not hatch after this period were regarded as nonviable. Percent reduction in hatchability was calculated using the following formula:

Egg mortality (\%)

$$
=100-\left(\frac{\text { No. un-hatched eggs/treatment }}{\text { Total no. of eggs/treatment }} \times 100\right)
$$

The percentage of egg mortality was subjected to analysis of variance (ANOVA), and the critical difference (CD; $p=0.05)$ was calculated [33].

\subsubsection{Microplot field study}

A microplot field trial was conducted to evaluate the efficacy of NKP extract against red spider mites. Treatments included were (1) NKP @ 2.5\% + botanical synergist @ 2.5\%, (2) the recommended standard acaricide and (3) untreated control. Pretreatment assessment of the red spider mite population was made on 15 leaves randomly collected from each treatment. Spraying was done using a handoperated knapsack sprayer using a spray volume of 1.5 I/plot $\left(37.5 \mathrm{~m}^{2}\right)$. Care was taken to drench the bushes for
The data obtained on the population density of red spider mites before and after treatments were subjected to analysis of variance (ANOVA), and the critical difference $(C D ; p=0.05)$ was calculated [33].

\subsubsection{Large-scale field study}

Large-scale field trials were also conducted in tea gardens representing three different geographical locations [Ambiok Tea Garden, Darjeeling $\left(27^{\circ} 0^{\prime} 7^{\prime \prime} \mathrm{N}, 88^{\circ}\right.$ $42^{\prime} 12^{\prime \prime}$ E longitude), Tocklai Tea Research Institute (TTRI) experimental plot, Assam ( $26^{\circ} 45^{\prime} 40.7^{\prime \prime} \mathrm{N}, 94^{\circ} 10^{\prime} 08.2^{\prime \prime}$ E longitude), and the Tea Research Association, NBRRDC experimental plot, Nagrakata $\left(26^{\circ} 54^{\prime} 0^{\prime \prime} \mathrm{N}, 88^{\circ} 55^{\prime} 0^{\prime \prime} \mathrm{E}\right.$ longitude)] to evaluate the efficacy of the extract of NKP and botanical synergist. Each trial was conducted in a randomized block design (RBD) with six treatments and four replications, each plot consisting of 100 bushes. Pre- and post-treatment assessments were carried out as described earlier in the micro-plot study.

\subsubsection{Pesticide residue study}

To evaluate the pesticide residue (if any) after application of the NKP and botanical synergist in made tea, a field trial was carried out. Three treatments were used, and each treatment was replicated in three different plots consisting of 100 bushes each. Two different doses [(1) $2.5 \mathrm{~kg}$ $\mathrm{NKP}+2.5 \mathrm{~kg}$ of botanical synergist and (2) $5 \mathrm{~kg} \mathrm{NKP}+5 \mathrm{~kg}$ of botanical synergist in $100 \mathrm{I}$ of water, respectively)] were used for spraying in the treated plots, and only water was sprayed in the control plot. Tea shoots consisting of three leaves and a bud were harvested at different time intervals: 0 day (3 $\mathrm{h}$ after application), 1, 3, 5, 7, 14 and 21 days. Fresh samples were used for estimation of residues. Black tea samples were manufactured using a mini CTC machine with the leaf samples collected from the trial plots for residue analysis using LC-MS/MS [make and model: 6460-A by Agilent Technologies, USA; column: Eclipse Plus $C_{18}$ $(100 \times 4.6 \mathrm{~mm} ; 3.5 \mu \mathrm{m})]$. 


\subsubsection{Phytotoxic effect, tainting and organoleptic test}

2.3.7.1 Phytotoxicity test To evaluate the phytotoxicity effect of the NKP and botanical synergist (at ' $X$ ' and ' $2 X$ ' dose) on tea leaves, a field trial was carried out. Three treatments were used: (1) $2.5 \mathrm{~kg} \mathrm{NKP}+2.5 \mathrm{~kg}$ botanical synergist, (2) $5 \mathrm{~kg} \mathrm{NKP}+5 \mathrm{~kg}$ botanical synergist in $100 \mathrm{I}$ of water, respectively, and (3) an untreated control, and each treatment was replicated three times. Spraying was done with a hand-operated knapsack sprayer using a spray volume of $400 \mathrm{l} / \mathrm{ha}$. Observations were taken up to 28 days after the first spraying of NKAE to assess the visual phytotoxicity symptoms such as injury on leaf tips, injury on leaf surfaces, leaf wilting, necrosis, vein clearing, epinasty and hyponasty. Phytotoxicity symptoms were assessed on a 10-point scale.

Phytotoxicity rating scale (PRS)

\begin{tabular}{lc}
\hline Crop response/crop injury & Rating \\
\hline $0-00$ & 0 \\
$1-10 \%$ & 1 \\
$11-20 \%$ & 2 \\
$21-30 \%$ & 3 \\
$31-40 \%$ & 4 \\
$41-50 \%$ & 5 \\
$51-60 \%$ & 6 \\
$61-70 \%$ & 7 \\
$71-80 \%$ & 8 \\
$81-90 \%$ & 9 \\
$91-100 \%$ & 10 \\
\hline
\end{tabular}

Rating was recorded individually for yellowing, stunting, necrosis, epinasty, hyponasty, etc. [2]

2.3.7.2 Tainting test To determine whether the application of the NKP and botanical synergist on tea plants imparts any taint to the CTC black tea manufactured from the treated leaves, an experiment was conducted at the Tea Research Association, NBRRDC experimental plot, using the extracts: (1) $2.5 \mathrm{~kg} \mathrm{NKP}+2.5 \mathrm{~kg}$ of botanical synergist and (2) $5 \mathrm{~kg} \mathrm{NKP}+5 \mathrm{~kg}$ of botanical synergist in $100 \mathrm{I}$ of water were prepared and applied using a handoperated knapsack sprayer using a spray volume of $400 \mathrm{l} /$ ha. The untreated control plots were sprayed with water. Shoots were harvested on 1, 3, 5, 7, 10 and 14 days after spraying and processed separately in a mini CTC (crush, tear and curl) machine for making black tea. The samples were forwarded to professional tasters and subjected to organoleptic evaluation for assessment of taint (if any).

\section{Results}

\subsection{LC $_{50}$ study}

Data obtained from the $\mathrm{LC}_{50}$ studies were analyzed by SPSS17 for probit analysis, the values were plotted on a fitted line plot for the regression equation, and the $\mathrm{LC}_{50}$ value was calculated. The results of the percent mortality of red spider mites against each concentration are presented in Table 1. The values of percent mortality were plotted against different concentrations of NKP after mixing with the botanical synergist, and a significant increase of red spider mite mortality was observed in all the test concentrations with increasing concentration (Fig. 1). LC 50 was found to be $2.3 \%$ after $48 \mathrm{~h}$.

\subsection{Ovicidal activity}

The results of the ovicidal activity of NKP extract are presented in Table 2 . The percentage egg mortality was low $(\geq 50 \%)$ when they were treated with NKP $2.5 \%$ (stand alone); however, when the same dose of NKP was mixed with the botanical synergist @ 2.5\%, it showed approximately $99 \%(p<0.05)$ mortality of eggs, whereas standard acaricide inflicted only $77.3 \%$ egg mortality.

\subsection{Micro-plot field study}

The results of the micro-plot field study conducted against red spider mites are given in Table 3. After two rounds of application at weekly intervals, a $72.6 \%$ reduction of red

Table 1 Percent mortality of adult red spider mites with different doses of 5\% (NKP @ $2.5 \mathrm{~g}$ and organic synergist @ $2.5 \mathrm{~g}$ )

\begin{tabular}{lccc}
\hline Treatment/dose & \multicolumn{3}{l}{$\begin{array}{l}\text { Mean } \% \text { mortality* of red spider mites } \pm \text { SE } \\
\text { after }\end{array}$} \\
\cline { 2 - 4 } & $24 \mathrm{~h}$ & $48 \mathrm{~h}$ & $72 \mathrm{~h}$ \\
\hline Control & $0 \pm 0.0$ & $0 \pm 0.0$ & $0 \pm 0.0$ \\
$0.5 \%$ & $7 \pm 0.14$ & $23 \pm 0.19$ & $37 \pm 0.74$ \\
$1.0 \%$ & $17 \pm 1.11$ & $30 \pm 1.15$ & $43 \pm 1.54$ \\
$2.0 \%$ & $27 \pm 1.14$ & $43 \pm 2.14$ & $63 \pm 2.12$ \\
$3.0 \%$ & $37 \pm 1.24$ & $67 \pm 2.24$ & $80 \pm 3.14$ \\
$4.0 \%$ & $60 \pm 2.14$ & $73 \pm 2.35$ & $90 \pm 3.41$ \\
$5.0 \%$ & $73 \pm 2.14$ & $80 \pm 2.15$ & $93 \pm 3.14$ \\
$6.0 \%$ & $63 \pm 1.28$ & $83 \pm 2.14$ & $87 \pm 2.25$ \\
$7.0 \%$ & $77 \pm 2.16$ & $87 \pm 2.17$ & $90 \pm 3.15$ \\
$8.0 \%$ & $83 \pm 3.11$ & $87 \pm 3.25$ & $93 \pm 3.45$ \\
$9.0 \%$ & $93 \pm 3.43$ & $100 \pm 3.41$ & $100 \pm 3.41$ \\
$10 \%$ & $97 \pm 3.11$ & $100 \pm 3.41$ & $100 \pm 3.41$ \\
\hline
\end{tabular}

*Values represent mean of three replications \pm SE 
Fig. 1 Regression equation with fitted line plots

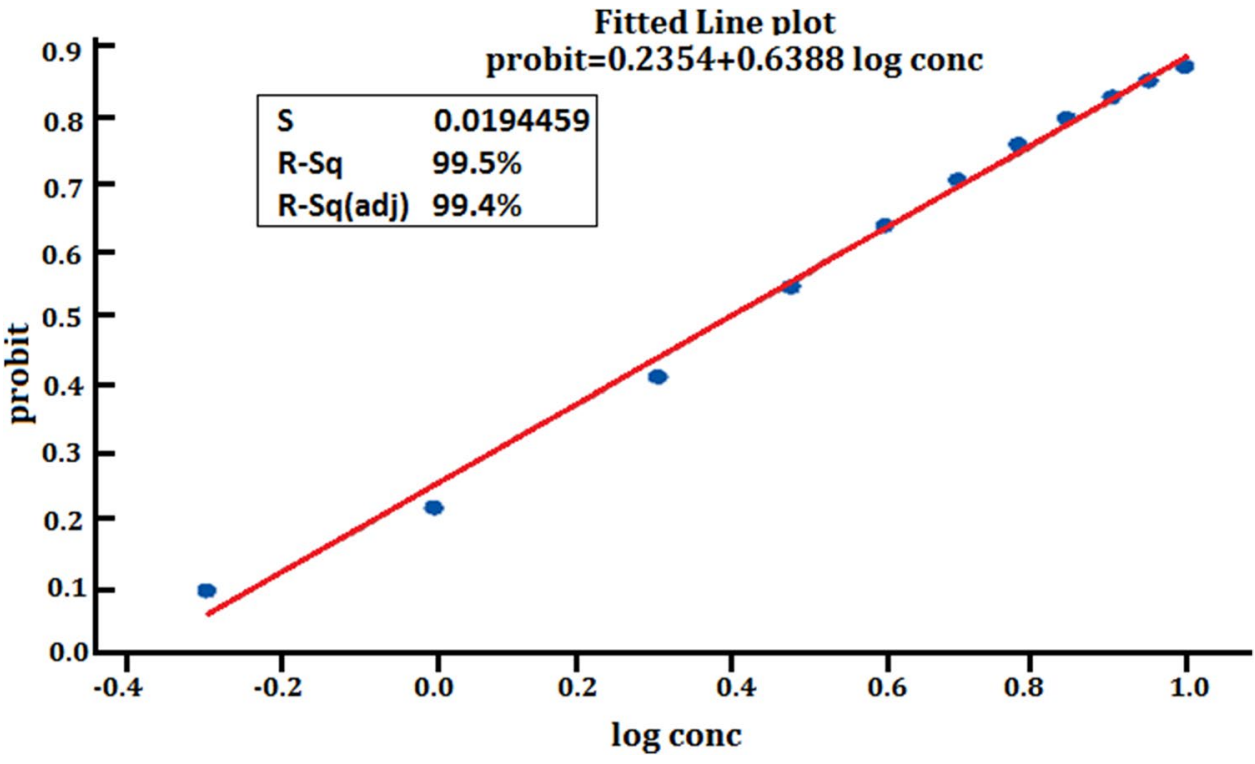

Table 2 Ovicidal activity of NKP and botanical synergist on the eggs of red spider mites

\begin{tabular}{ll}
\hline Treatment & $\begin{array}{l}\text { Egg mortality (\%) } \\
\text { Mean } \pm \text { SE }(n=30)\end{array}$ \\
\hline NKP @ 2.5\% & $50.0 \pm 1.3^{\mathrm{a}}$ \\
NKP @ 2.5\%+botanical synergist @ 2.5\% & $99.0 \pm 3.2^{\mathrm{b}}$ \\
Standard acaricide & $77.3 \pm 2.4^{\mathrm{c}}$ \\
Control & 0.0 \\
CD $(p=0.05)$ & 2.45 \\
\hline
\end{tabular}

Numbers with different letters are significantly different at the $5 \%$ level $(p<0.05)$

spider mites was recorded when NKP @ 2.5\% was mixed with botanical synergist @ 2.5\% compared with a 65.1\% reduction with the standard acaricide.

\subsection{Large-scale field study}

Data recorded on bioefficacy under large-scale field trials conducted at different locations against red spider mites are summarized in Tables 4,5 and 6 . The results indicated that application of NKP @ 2.5\% and synergist @ 2.5\% significantly decreased the number of red spider mites in all three locations compared with the untreated control, and the results are comparable to those of the commercial neem formulation (Aza@5\%) and standard acaricide.

\subsection{Pesticide residue study}

The result of the residue analysis indicated that application of NKP and botanical synergist did not leave any undesirable residues on either green leaves or made tea samples after the 7th day (Table 7).
Table 3 Effect of NKP and botanical synergist on the red spider mite under micro-plot field conditions

\begin{tabular}{|c|c|c|c|c|}
\hline \multirow[t]{2}{*}{ Dose/treatment } & \multirow[t]{2}{*}{$\begin{array}{l}\text { Pre-treatment observation } \\
\text { (average no. of mites/leaf) }\end{array}$} & \multicolumn{3}{|c|}{$\begin{array}{l}\text { Percent reduction over pre-treatment } \\
\text { observation after* }\end{array}$} \\
\hline & & 7 days & 14 days & Average \\
\hline $\begin{array}{l}\text { NKP @ } 2.5 \%+\text { botanical } \\
\text { synergist @ } 2.5 \%\end{array}$ & 49.7 & $\begin{array}{l}32.2 \\
(64.8 \%)\end{array}$ & $\begin{array}{l}36.0 \\
(72.6 \%)\end{array}$ & $34.1(68.7 \%)$ \\
\hline Standard acaricide & 52.5 & $\begin{array}{l}31.0 \\
(59.4 \%)\end{array}$ & $\begin{array}{l}34.0 \\
(65.1 \%)\end{array}$ & 32.5 (62.2\%) \\
\hline Control & 54.0 & $\begin{array}{l}58.0 \\
(7.4 \%)\end{array}$ & $\begin{array}{l}53 \\
(-1.8 \%)\end{array}$ & $\begin{array}{l}55.5 \\
(2.7 \%)\end{array}$ \\
\hline $\mathrm{CD}(p=0.05)$ & NS & 1.77 & 2.89 & 2.33 \\
\hline
\end{tabular}

*Values represent the mean number of mites/leaf. Figures in parentheses indicate percent control over pre-treatment observation 
Table 4 Large-scale field trial on the evaluation of the NKP and botanical synergist against red spider mites (at Ambiok Tea Garden, Darjeeling)

\begin{tabular}{|c|c|c|c|c|c|c|c|}
\hline \multirow[t]{2}{*}{ T. no } & \multirow[t]{2}{*}{ Treatment } & \multirow[t]{2}{*}{ Dosage/ha } & \multicolumn{5}{|c|}{ No. of red spider mites/40 leaves } \\
\hline & & & Pre treatment & 1 week after 1 spray & 2 weeks after 1 spray & $\begin{array}{l}3 \text { weeks } \\
\text { after } 2 \\
\text { sprays }\end{array}$ & $\begin{array}{l}4 \text { weeks } \\
\text { after } 2 \\
\text { sprays }\end{array}$ \\
\hline $\mathrm{T} 1$ & NKP + synergist & $1.25 \%+1.25 \%$ & $\begin{array}{l}1014 \\
(15.91)\end{array}$ & $\begin{array}{l}818 \\
(14.29) \mathrm{a}\end{array}$ & $\begin{array}{l}447 \\
(10.58) \mathrm{a}\end{array}$ & $\begin{array}{l}392 \\
(9.92) a\end{array}$ & $\begin{array}{l}460 \\
(10.75) a\end{array}$ \\
\hline $\mathrm{T} 2$ & NKP + synergist & $2.5 \%+2.5 \%$ & $\begin{array}{l}905 \\
(15.03)\end{array}$ & $\begin{array}{l}606 \\
(12.29) \mathrm{b}\end{array}$ & $\begin{array}{l}272 \\
(8.30) b\end{array}$ & $\begin{array}{l}264 \\
(8.15) b\end{array}$ & $\begin{array}{l}312 \\
(8.87) b\end{array}$ \\
\hline T3 & $\begin{array}{l}\text { Commercial neem } \\
\text { formulation (Aza } \\
5 \%)\end{array}$ & $0.06 \%$ & $\begin{array}{l}885 \\
(14.73)\end{array}$ & $\begin{array}{l}643 \\
(12.55) \mathrm{b}\end{array}$ & $\begin{array}{l}380 \\
(9.77) \mathrm{c}\end{array}$ & $\begin{array}{l}377 \\
(9.75) \mathrm{a}\end{array}$ & $\begin{array}{l}404 \\
(10.08) a\end{array}$ \\
\hline T4 & Standard acaricide & $0.25 \%$ & $\begin{array}{l}881 \\
(14.82)\end{array}$ & $\begin{array}{l}701 \\
(13.24) c\end{array}$ & $\begin{array}{l}327 \\
(9.08) c\end{array}$ & $\begin{array}{l}288 \\
(8.49) \mathrm{c}\end{array}$ & $\begin{array}{l}324 \\
(9.04) b\end{array}$ \\
\hline \multirow[t]{2}{*}{ T5 } & Control & Water spray & $\begin{array}{l}580 \\
(12.08)\end{array}$ & $\begin{array}{l}752 \\
(13.74) c\end{array}$ & $\begin{array}{l}860 \\
(14.70) d\end{array}$ & $\begin{array}{l}924 \\
(15.23) d\end{array}$ & $\begin{array}{l}1088 \\
(9.64) c\end{array}$ \\
\hline & $\mathrm{CD}$ at $p=0.05$ & & 2.28 & $\mathrm{~N} / \mathrm{A}$ & 1.39 & 1.02 & 0.893 \\
\hline
\end{tabular}

Figures in parentheses are transformed values of $\sqrt{ }(x+1)$. Figures followed by the same letters in a vertical column are not significantly different at the $5 \%$ level

Table 5 Large-scale field trial on the evaluation of NKP and botanical synergist against red spider mites (at the NBRRDC experimental plot, West Bengal)

\begin{tabular}{|c|c|c|c|c|c|c|c|}
\hline \multirow[t]{2}{*}{ T. no } & \multirow[t]{2}{*}{ Treatment } & \multirow[t]{2}{*}{ Dosage/ha } & \multicolumn{5}{|c|}{ No. of red spider mites/30 leaves } \\
\hline & & & Pre-treatment & 1 week after 1 spray & $\begin{array}{l}2 \text { weeks after } 1 \\
\text { spray }\end{array}$ & $\begin{array}{l}3 \text { weeks after } 2 \\
\text { sprays }\end{array}$ & $\begin{array}{l}4 \text { weeks after } \\
2 \text { sprays }\end{array}$ \\
\hline $\mathrm{T} 1$ & NKP + synergist & $1.25 \%+1.25 \%$ & $\begin{array}{l}1175 \\
(19.75)\end{array}$ & $\begin{array}{l}954 \\
(17.78) a\end{array}$ & $\begin{array}{l}938 \\
(17.54) a\end{array}$ & $\begin{array}{l}652 \\
(14.63) a\end{array}$ & $\begin{array}{l}743 \\
(15.71) a\end{array}$ \\
\hline $\mathrm{T} 2$ & NKP + Synergist & $2.5 \%+2.5 \%$ & $\begin{array}{l}835 \\
(16.60)\end{array}$ & $\begin{array}{l}379 \\
(11.26) \mathrm{b}\end{array}$ & $\begin{array}{l}213 \\
(8.19) \mathrm{b}\end{array}$ & $\begin{array}{l}204 \\
(8.11) \mathrm{b}\end{array}$ & $\begin{array}{l}273 \\
(9.44) \mathrm{b}\end{array}$ \\
\hline T3 & $\begin{array}{l}\text { Commercial } \\
\text { neem formula- } \\
\text { tion (Aza 5\%) }\end{array}$ & $0.06 \%$ & $\begin{array}{l}951 \\
(17.67)\end{array}$ & $\begin{array}{l}570 \\
(13.72) \mathrm{c}\end{array}$ & $\begin{array}{l}409 \\
(11.60) c\end{array}$ & $\begin{array}{l}399 \\
(10.77) c\end{array}$ & $\begin{array}{l}420 \\
(10.88) b\end{array}$ \\
\hline T4 & $\begin{array}{l}\text { Standard acari- } \\
\text { cide }\end{array}$ & $0.25 \%$ & $\begin{array}{l}907 \\
(17.23)\end{array}$ & $\begin{array}{l}509 \\
(13.05) c\end{array}$ & $\begin{array}{l}307 \\
(9.99) \mathrm{b}\end{array}$ & $\begin{array}{l}298 \\
(9.86) c\end{array}$ & $\begin{array}{l}602 \\
(13.21) c\end{array}$ \\
\hline T5 & Control & Water spray & $\begin{array}{l}731 \\
(15.50)\end{array}$ & $\begin{array}{l}925 \\
(17.55) a\end{array}$ & $\begin{array}{l}693 \\
(14.96) d\end{array}$ & $\begin{array}{l}1031 \\
(18.48) d\end{array}$ & $\begin{array}{l}1171 \\
(19.75) d\end{array}$ \\
\hline \multicolumn{3}{|c|}{ C.D. at $p=0.05$} & $\mathrm{~N} / \mathrm{A}$ & 3.28 & 3.07 & 3.54 & 4.60 \\
\hline
\end{tabular}

Figures in parentheses are transformed values of $\sqrt{ }(x+1)$. Figures followed by the same letters in a vertical column are not significantly different at the $5 \%$ level

\subsection{Phytotoxic effect, tainting and organoleptic test}

Observations on the phytotoxicity on the leaf surface, leaf tips, wilting, necrosis, vein clearing, peasantry and hyponasty ranged between 1 and 10\% (grade 1), revealing that NKAE is non-phytotoxic to tea. Similarly, tea shoots harvested 1, 3, 5, 7, 10 and 14 days after the application of NKP and botanical synergist were manufactured in the miniature CTC unit at NBRRDC, and the report from professional tea tasters revealed that the made tea samples had no taint.

\section{Discussion}

The neem Azadirachta indica A. Juss (Meliaceaee) and its products have a strong insecticidal property, which has already been established [12, 14, 29-31]. Babu et al. [2] reported neem kernel aqueous extract to be an excellent control against red spider mites infesting tea. In the present work we applied an approach to increase the insecticidal activity of NKP using dried powder of the pods/ seeds of Prosopis juliflora as a botanical synergist against 
Table 6 Large-scale field trial on the evaluation of NKP and botanical synergist against red spider mites (at TTRI, experimental plot, ASSAM)

\begin{tabular}{|c|c|c|c|c|c|c|c|}
\hline \multirow[t]{2}{*}{ T. no. } & \multirow[t]{2}{*}{ Treatment } & \multirow[t]{2}{*}{ Dosage/ha } & \multicolumn{5}{|c|}{ No. of red spider mites/30 leaves } \\
\hline & & & Pre-treatment & 1 week after 1 spray & 2 week after 1 spray & $\begin{array}{l}3 \text { week } \\
\text { after } 2 \\
\text { sprays }\end{array}$ & $\begin{array}{l}4 \text { weeks } \\
\text { after } 3 \\
\text { sprays }\end{array}$ \\
\hline $\mathrm{T} 1$ & NKP + synergist & $1.25 \%+1.25 \%$ & $\begin{array}{l}1644 \\
(23.42)\end{array}$ & $\begin{array}{l}1354 \\
(21.27) a\end{array}$ & $\begin{array}{l}787 \\
(16.21) a\end{array}$ & $\begin{array}{l}863 \\
(16.98) a\end{array}$ & $\begin{array}{l}923 \\
(17.55) a\end{array}$ \\
\hline $\mathrm{T} 2$ & NKP + synergist & $2.5 \%+2.5 \%$ & $\begin{array}{l}1617 \\
(23.12)\end{array}$ & $\begin{array}{l}1267 \\
(20.54) a\end{array}$ & $\begin{array}{l}623 \\
(14.44) b\end{array}$ & $\begin{array}{l}642 \\
(14.65) b\end{array}$ & $\begin{array}{l}667 \\
(14.91) b\end{array}$ \\
\hline T3 & $\begin{array}{l}\text { Commercial neem } \\
\text { formulation (Aza } \\
5 \%)\end{array}$ & $0.06 \%$ & $\begin{array}{l}1589 \\
(22.98)\end{array}$ & $\begin{array}{l}1172 \\
(19.79) a\end{array}$ & $\begin{array}{l}542 \\
(13.47) b\end{array}$ & $\begin{array}{l}567 \\
(13.78) b\end{array}$ & $\begin{array}{l}611 \\
(14.27) b\end{array}$ \\
\hline T4 & Standard acaricide & $0.25 \%$ & $\begin{array}{l}1723 \\
(23.98)\end{array}$ & $\begin{array}{l}976 \\
(11.2) \mathrm{b}\end{array}$ & $\begin{array}{l}689 \\
(15.53) a\end{array}$ & $\begin{array}{l}551 \\
(14.23) b\end{array}$ & $\begin{array}{l}655 \\
(14.37) b\end{array}$ \\
\hline T5 & Control water spray & & $\begin{array}{l}1590 \\
(23.04) \mathrm{c}\end{array}$ & $\begin{array}{l}1650 \\
(23.47) c\end{array}$ & $\begin{array}{l}1683 \\
(23.71) c\end{array}$ & $\begin{array}{l}1632 \\
(23.33) c\end{array}$ & \\
\hline C.D. at $p=0.05$ & & & $\mathrm{~N} / \mathrm{A}$ & 1.52 & 1.57 & 1.53 & 1.59 \\
\hline
\end{tabular}

Figures in parentheses are transformed values of $\sqrt{ }(x+1)$. Figures followed by the same alphabets in a vertical column are not significantly different at the $5 \%$ level

Table 7 Residue level $(\mu \mathrm{g} / \mathrm{g})$ of azadirachtin in green leaf and made tea

\begin{tabular}{|c|c|c|c|c|}
\hline \multirow[t]{4}{*}{ Sampling day } & \multicolumn{4}{|l|}{ Treatments } \\
\hline & \multicolumn{2}{|l|}{ Green leaf } & \multicolumn{2}{|l|}{ Made tea } \\
\hline & $\begin{array}{l}2.5 \mathrm{~kg} \mathrm{NKP}+2.5 \mathrm{~kg} \\
\text { synergist }\end{array}$ & $5 \mathrm{~kg} \mathrm{NKP}+5 \mathrm{~kg}$ synergist & $2.5 \mathrm{~kg} \mathrm{NKP}+2.5 \mathrm{~kg}$ synergist & $5 \mathrm{~kg} \mathrm{NKP}+5 \mathrm{~kg}$ synergist \\
\hline & Residue in $(\mu \mathrm{g} / \mathrm{g})$ & Residue in $(\mu \mathrm{g} / \mathrm{g})$ & Residue in $(\mu \mathrm{g} / \mathrm{g})$ & Residue in $(\mu \mathrm{g} / \mathrm{g})$ \\
\hline 0 day & 5.47 & 10.54 & 40.09 & 73.33 \\
\hline 1 day & 0.60 & 0.89 & 2.09 & 2.86 \\
\hline 3 days & 0.14 & 0.23 & 0.32 & 0.36 \\
\hline 5 days & BDL & 0.18 & 0.24 & 0.29 \\
\hline 7 days & $\mathrm{BDL}$ & $\mathrm{BDL}$ & 0.14 & 0.19 \\
\hline 14 days & $\mathrm{BDL}$ & $\mathrm{BDL}$ & 0.02 & 0.05 \\
\hline 21 days & $\mathrm{BDL}$ & $\mathrm{BDL}$ & $\mathrm{BDL}$ & $\mathrm{BDL}$ \\
\hline
\end{tabular}

$B D L$ below the detectable limit, $L O Q$ of azadirachtin: $0.01 \mu \mathrm{g} / \mathrm{g}$

the eggs and adults of red spider mites, and the result showed that both the ovicidal and adulticidal activity of NKP significantly increased $(p<0.05)$ with the addition of the botanical synergist. NKP @ 2.5\% mixed with botanical synergist @ 2.5\% yielded the highest egg mortality compared with NKP @ 2.5\% (alone). Babu et al. [2] observed significant egg mortality of neem kernel powder at a $5 \%$ dose against red spider mites. Roobakkumar et al. [26] reported a maximum $90 \%$ egg mortality of red spider mites with 5\% NKAE application.

Although botanical pesticides prepared from the neem Azadirachta indica are becoming prevalent because of their biodegradability, lesser persistence, lesser toxicity to non-target organisms and easy availability, they are less effective than chemical-based pesticides $[3,10]$. To inhance the stability of these botanical pesticides, many studies have been carried out [25]. Synergism between chemical insecticides and different botanicals against different insect pests is well documented $[8,15,25]$. Synergistic activities of formulations are well known for their toxic effect, and botanicals play an important role as a synergist in insect pest management $[3,34]$.

In the current investigation, the dried powder of Prosopis julifora was used as a botanical synergist to enhance the efficacy of NKP. Even at 2.5\%, significant increases in the percentage of egg mortality up to $99 \%$ were recorded. Spraying of NKP @ 5\% significantly reduced the red spider mite population compared with the untreated control and was on par with that of standard acaricide [2]. The laboratory and field experiments using NKP and the botanical 
synergist revealed that NKP at the concentration of $2.5 \%$ when mixed with botanical synergist @ $2.5 \%$ was effective in controlling red spider mites infesting tea. Deka et al. [11] reported the botanical synergist enhanced the efficacy of neem kernel powder extract and different acaricides such as Fenpyroximate $5 \mathrm{EC}$, Ethion $50 \mathrm{EC}$ and Spiromesifen 22.9 SC against red spider mites under laboratory conditions. This organic synergist enhanced the efficacy of NKP (even at $2.5 \%$ NKP) at almost $45 \%$ [11]. Babu et al. [2] reported a maximum of $72.3 \%$ mortality of red spider mites $72 \mathrm{~h}$ after spraying of NKAE, and based on the laboratory and field experiments they reported that NKAE at $5 \%$ concentration was effective in controlling tea red spider mites. Several commercial neem-based formulations were also tested and found effective against different species of mites [20]. However, NKAE was found to be more effective against red spider mites @ 5\% [2]. Patanjali et al. [23] reported the botanical synergist enhances the insecticidal and larvicidal effect of NKP against Ades agypti. The mortality of eggs and adult red spider mites even at a lower concentration of neem kernel powder signifies that this botanical synergist increases the stability and bioavailability of azadirachtin and compounds in neem kernel powder. This might be due to the presence of glycosidic compounds present in Prosopis juliflora, which increase the toxicity of neem kernel powder without having their own toxic effect on test insects [16, 17, 32, 35]. Addition of an equal amount of the powder of Prosopis juliflora enhanced the efficacy of neem kernel powder extract by almost $20-40 \%$ compared with the individual treatments, which could be further exploited by including this as a synergist for reducing the pesticide load on tea. Currently, applications of synergist in different agricultural practices to control different pests are very common and are contributing significantly to improving the efficacy of insecticides, especially where the problem of development of resistance has arisen over several decades [6]. Babu et al. [2] reported that NKAE is non-phytotoxic and safer for beneficial insects such as predators, and it does not leave any undesirable residues on black tea. Our study is also in line with these findings. Observations on the phytotoxicity on tea leaves revealed that NKP and the botanical synergist are non-phytotoxic to tea, and the teas made from the leaves tested by professional tea tasters reported that the made tea samples had no taint.

\section{Conclusion}

The present investigation attempted to evaluate and establish the activity of Prosopis juliflora as a botanical synergist. We applied a synergistic approach to increase the acaricidal effect of neem kernel powder extract against one of the major tea pests, red spider mite. The combination of neem kernel powder with the botanical synergist showed significantly better results compared with neem kernel powder (stand alone) and standard acaricide. Application of the neem product with Prosopis juliflora reduces the dose and application, even with an increase in its efficacy. Thus, the present study suggests that Prosopis juliflora used as a botanical synergist significantly increased the toxicity of neem kernel powder and provided an ecofriendly and economically efficient formulation of neem kernel powder for red spider mite management without any toxic effect on tea plants or consumers.

Acknowledgements The authors thank the Ministry of Chemicals \& Fertilizers, Government of India, New Delhi, for the financial support rendered in the form of a project. The technical support received from the Institute of Pesticide Formulation Technology, Gurgaon, Haryana, is also acknowledged.

\section{Compliance with ethical standards}

Conflict of interest The authors declare that there is no conflict of interest regarding the publication of this paper.

\section{References}

1. Babu A, Muraleedharan N (2010) A notes on the use of pesticides for the control of insect and mite pests of tea in South India. UPASI Tea Research Institute, Nirar Dam BPO, Valparai

2. Babu A, Perumalsamy K, Sankara Rama Subramaniam M, Muraleedharan N (2008) Use of neem kernel aqueous extract for the management of red spider mite infesting tea in south India. J Plant Crops 36(3):393-397

3. Baki MA, Akhtar N, Rahman MM, Islam MN, Hossain M (2005) Synergistic action of Wedelia calendulacea Less. Plant extracts with lambda cyhalothrin on adult red flour beetle Tribolium castaneum Herbst. J Agron 4:18-22

4. Banerjee B (1971): The economics of prophylactic spraying against red spider, pp: 146-150. In Mature tea productivity proceedings of the 25th Tocklai conference, 17-19 December 1971, TRA, Jorhat, Assam (Edited by the Director, Tocklai Experimental Station, Jorhat), Assam Printing Works Private Limited, Jorhat

5. Bansal SK, Singh KV, Sharma S, Sherwani MRK (2012) Laboratory observations on the larvicidal efficacy of three plant species against mosquito vectors of malaria, dengue/dengue hemorrhagic fever (DF/DHF) and lymphatic filariasis in the semi-arid desert. J Environ Biol 33:617-621

6. Bernard CB, Philogene BJ (2009) Insecticide synergists: role, importance and perspectives. J Toxicol Environ Health 38(2):199-223. https://doi.org/10.1080/15287399309531712

7. Cavalcante GM, Moreira AFC, Vasconcelos SD (2006) Insecticidal potential of aqueous extracts from arboreous species against whitefly. Pesqui Agropecu Bras 41:9-14

8. Constanski KC, Zorzetti J, Santoro PH, Hoshino AT, Neves PMOJ (2016) Inert powders alone or in combination with neem oil for controlling Spodoptera eridania and Spodoptera frugiperda (Lepidoptera: Noctuidae) larvae. Ciências Agrárias 37:1801-1810

9. Das GM (1959) Bionomics of tea red spider, Oligonychus coffeae (Nietner). Bull ENT Res 50:265-275 
10. Debashri M, Tamal M (2012) A review on efficacy of Azadirachta indica A. Juss based biopesticides: an Indian perspective. Res J Recent Sci 1:94-99

11. Deka B, Babu A, Sarkar S, Mandal S, Kundu N, Patanjali PK, Bhandari P (2017) Bioactivity of an botanical synergist in enhancing the efficacy of neem kernel aqueous extract (NKAE) and three recommended acaricides in controlling tea red spider mite (Oligonychus Coffeae). J Tea Sci Res 7(8):40-45

12. Hamilton DP (1992) The wonders of the neem tree-revealed! Science 255(275):127-129

13. Helle W, Sabelis MW (1985) Spider mites: their biology, natural enemies and control. Elsevier Science Publishing Company Inc, New York, p 335

14. Jacobson $M$ (1986) The neem tree: natural resistance par excellence. In: Green MB, Hedin PA (eds) Natural resistance of plants of pests. Roles of allelochemicals. Chemical society symposium ser. no. 296. Washington, DC, pp 19-45

15. Khalequzzaman M, Khanom M (2006) Effects of cypermethrin alone and in combination with leaf and seed extracts of neem against adult Tribolium castaneum (Herbst). Univ J Zool Rajshahi Univ 25:45-49

16. Kumar A, De T, Mishra A, Oleandrin Mishra AK (2013) A cardiac glycosides with potent cytotoxicity. Pharmacogn Rev 7:131-139

17. Kumari A, Richa K, Prabha A, Singh NS, Sharma R, Patanjali PK (2017) Toxicity effects of neem oil with Prosopis juliflora (Leguminoseae) extract against Khapra beetle Trogoderma granarium (Everts.). Int J Entomol Res 2(6):49-53

18. Muraleedharan N (1992) Pest control in Asia. In: Wilson KC, Clifford MN (eds) Tea: cultivation to consumption. Chapman and Hall, London, pp 375-412

19. Muraleedharan N, Sudarmani DNP, Selvasundaram R (2005) Bioecology and management of the red spider mite infesting tea in south India. In: Proceedings of international symposium on innovation in tea science and sustainable development in tea industry. China Tea Science Society, Hangzhou China, pp 756-766

20. Muraleedharan N (1995) Annual report of UPASI scientific department. UPASI Tea Research Institute, Valparai, pp 63-80

21. Murugesan S, Baskaran S, Mahadevan NR (2004) Individual and combined effects of endosulfan with leaf extract of Prosopis juliflora L. on biochemical contents and fecundity of Spodoptera litura (Fabricius). Pestology 28:23-27

22. Pasiecznik NM, Felker P, Harris PJ, Harsh L, Cruz G, Tewari JC, Cadoret K, Maldonado LJ (2001) The Prosopis juliflora-Prosopis pallida complex: A monograph. 172, HDRA, Coventry, UK

23. Patanjali PK, Aggarwal A, Shrivastav B, Jhelum V (2009) Synergistic insecticidal and larvicidal botanical compositions application no. 1627/DEL/2009, 2011

24. Pugazhvendan SR, Ross PR, Elumalai K (2012) Insecticidal and repellant activities of four indigenous medicinal plants against stored grain pest, Tribolium castaneum (Herbst) (Coleoptera: Tenebrionidae). Asian Pac J Trop Dis 2:S16-S20
25. Radhika SA, Sahayaraj K (2014) Synergistic effects of monocrotophos with botanical oils and commercial neem formulation on Spodoptera litura (Fab.) (Lepidoptera: Noctuidae). J Biopestic 7:152-159

26. Roobakkumar A, Subramaniam MSR, Babu A, Muraleedharan N (2010) Bioefficacy of certain plant extracts against the red spidermite, Oligonychus coffeae (Nietner) (Acarina: Tetranychidae) infesting tea in Tamil Nadu, India. Int J Acarol 36:255-258

27. Roy S, Handique G, Muraleedharan N, Dashora K, Roy SM, Mukhopadhyay A, Babu A (2016) Use of plant extracts for tea pest management in India. Appl Microbiol Biotechnol 100:4831-4844

28. Roy S, Mukhopadhyay A, Gurusubramanian G (2010) Field efficacy of a biopesticide prepared from Clerodendrum viscosum Vent. (Verbenaceae) against two major tea pests in the sub Himalayan tea plantation of North Bengal, India. J Pest Sci 83:371-377

29. Roy S, Muraleedharan N, Mukhopadhyay A (2014) The red spider mite, Oligonychus coffeae (Acari: Tetranychidae): its status, biology, ecology and management in tea plantations. Exp Appl Acarol 63:431-463

30. Schmutterer $H$, Ascher KRS (1987) Natural pesticides from the neem trees Azadirachta indica A.Juss and other tropical plants. In: Proceedings of the 3rd International Neem Conference, Nairobi, Kenya 10-15 July, 1986. GTZ, D-6236 Eschborn 1

31. Schmutterer H, Ascher KRS, Rembolod H (1981) Natuaral pesticides from the neem trees Azadirachta indica A. Juss. In: Proceedings of 1 st International Neem Conference, Rottach-Egern, 16-18, June 1980. GTZ, D-6236 Eschborn 1

32. Singh B, Singh PR, Mohanty MK (2012) Toxicity of a plant based mosquito repellent/killer. Interdiscip Toxicol 5:184-191

33. Snedecor GW, Cochran WG (1989) Statistical methods, 8th edn. lowa State University Press, Ames, lowa, p 503

34. Srivastava CN, Mhan L, Sharma P, Maurya P (2011) A review on prospective of synergistic approach in insect pest management. J Entomol Res 35(3):255-266

35. Wondafrash M, Getu E, Terefe G (2012) Neem, Azadirachta indica (A. Juss) extracts negatively influenced growth and development of African Bollworm, Helicoverpa armigera (Hubner) (Lepidoptera: Noctuidae). Acad J Entomol 5:22-27

36. Yadav R, Singh AV, Joshi S, Kumar M (2015) Antifungal and enzyme activity of endophytic fungi isolated from Ocimum sanctum and Aloe vera. Afr J Microbiol Res 9:1783-1788

37. Yadav R, Tyagi V, Tikar SN, Sharma AK, Mendki MJ, Jain AK, Sukumaran D (2014) Differential larval toxicity and oviposition altering activity of some indigenous plant extracts against dengue and chikungunya vector Aedes albopictus. J Arthropod Borne Dis 8:174-185

Publisher's Note Springer Nature remains neutral with regard to jurisdictional claims in published maps and institutional affiliations. 